\title{
Morphometric and Morphological Study of the Dental Roots of the Upper First Premolars
}

\author{
Estudio Morfométrico y Morfológico de las Raíces \\ Dentales de Primeros Premolares Superiores
}

\begin{abstract}
Nilton Alves
ALVES, N. Morphometric and morphological study of the dental roots of the upper first premolars. Int. J. Odontostomat., 4(2):111-115, 2010.

ABSTRACT: The knowledge of the dental anatomy, mainly the radicular portion, is of great importance to some specialities such as the Endodonty and Periodonty. The aim of this study was to analyse the radicular morphometry of the upper first premolars, checking the average length of the roots, and also, their inclinations and the location of furcation area in bi and three radiculars. In this study were used 659 human upper first premolars belonging to Department of Morphology of the School of Dentistry of Araraquara, UNESP, Brazil. The teeth were previously selected, so only the ones with perfect roots were used. The teeth were divided in three groups: mono radiculars, bi radiculars and three radiculars. After they had been separated, some specific measurements with a Brown \& Sharp digital paquimeter were done in each group. In our study we could conclude that: 1 - the upper first premolars mono radiculars presented an average radicular length higher than the bi radiculars and these ones, higher than the three radiculars; 2 - the upper first premolars bi radiculars presented an average radicular length higher for the vestibular root in relation to the palatine root, both roots presents higher inclination percentage for the distal. The furcation can be located in the middle third as well as in the apical third; 3 - the upper first premolars three radiculars present an average radicular length higher for the palatine root in relation to the vestibular roots. The radicular inclination is variable, and the distovestibular root presents higher inclination percentage for the mesial while the other roots for the distal. The furcation is located, in all the cases, at the middle third.
\end{abstract}

KEY WORDS: upper first premolar, morfometry, dental root.

\section{INTRODUCTION}

The knowledge of the dental anatomy, mainly the radicular portion, is of great importance to some specialities such as the Endodonty and Periodonty.

Regarding the upper first premolar, it is known that its radicular morphology is variable. It can be mono, bi or three radicular. According to Picosse (1979), the upper first premolar has, in more than $70 \%$ of the cases, a bifid root; on the other hand, Sicher \& Tandler (1942) says it occurs in approximately $50 \%$ of the cases. Bourdelle et al. (1937) declare that in $66 \%$ of the cases there are bi radiculars roots, in $30 \%$ mono radicular and in $4 \%$ they were three radiculars. Woelfel \& Scheid (2000) studied 200 teeth, $61 \%$ of them had two roots, $38 \%$ one root and $1 \%$ three roots.

Concerning the radicular length, there are also some discordant opinions among the authors. Fischer
(1907) and Black (1897) claimed that the maximum length of the root in the upper first molar would be $17.4 \mathrm{~mm}$ and its minimum length $9.2 \mathrm{~mm}$. However, Schwartz (1935) concluded that the maximum would be $13.7 \mathrm{~mm}$ and the minimum $9.8 \mathrm{~mm}$. According to Mühlreiter (1870) the maximum would be $14.0 \mathrm{~mm}$ and the minimum $10.0 \mathrm{~mm}$.

Woelfel \& Scheid, Silva \& Pécora (1998) and Madeira (2000) claim that the lingual root of the upper first premolars with a bifurcated root is shorter than the buccal root. Figún \& Garino (1989) says that the lingual root is always bigger than the vestibular root. DellaSerra \& Ferreira (1981) says that, when bifurcated, the palatine root is larger and shorter than the vestibular root, which is taller and flatter.

The aim of this study was to analyse the radicular 
morphometry of the upper first premolars, checking the average length of the roots, and also, their inclinations and the location of furcation area in bi and three radiculars.

\section{MATERIAL AND METHOD}

In this study were used 659 human upper first premolars belonging to Department of Morphology of the School of Dentistry of Araraquara, UNESP, Brazil. The sex, age, race of the person, and the reasons why the teeth were removed were not informed.

The teeth were previously selected, so only the ones with perfect roots were used. The teeth were divided in three groups: mono radiculars, bi radiculars and three radiculars. After they had been separated, some specific measurements with a Brown \& Sharp digital paquimeter were done in each group.

In all groups, the roots of each tooth were measured and then we could to obtain an average of the length of each root measured of each group.

The mesial or distal inclination of each root was also observed, so that a percentage of the radicular inclination between the groups could be obtained. The location of the furcation in the middle or apical thirds was observed in the bi radicular and three radicular teeth, the percentage for each group was also obtained.

\section{RESULTS}

The teeth were measured through the obtaintion of the root length, in millimeters, of each tooth. The radicular length is equivalent to the length from the top of the root until the cervical line (the limit between the tooth crown and the root). In the bi radiculars, both roots were measured, obtaining an average length for each root (vestibular and lingual roots). The same was done in the three radiculars, thus obtaining three averages of radicular length: one for the mesiovestibular root, one for the distovestibular and other for the palatine root.

For the mono radicular teeth, the average of the radicular length was $14.39 \mathrm{~mm}$. In the bi radiculars, the average was $13.43 \mathrm{~mm}$ for the vestibular root and $13.09 \mathrm{~mm}$ for the palatine root. In the three radiculars, the average was $11.25 \mathrm{~mm}$ for the mesiovestibular root, $10.56 \mathrm{~mm}$ for the distovestibular root, and $11.91 \mathrm{~mm}$ for the palatine root (Table I).

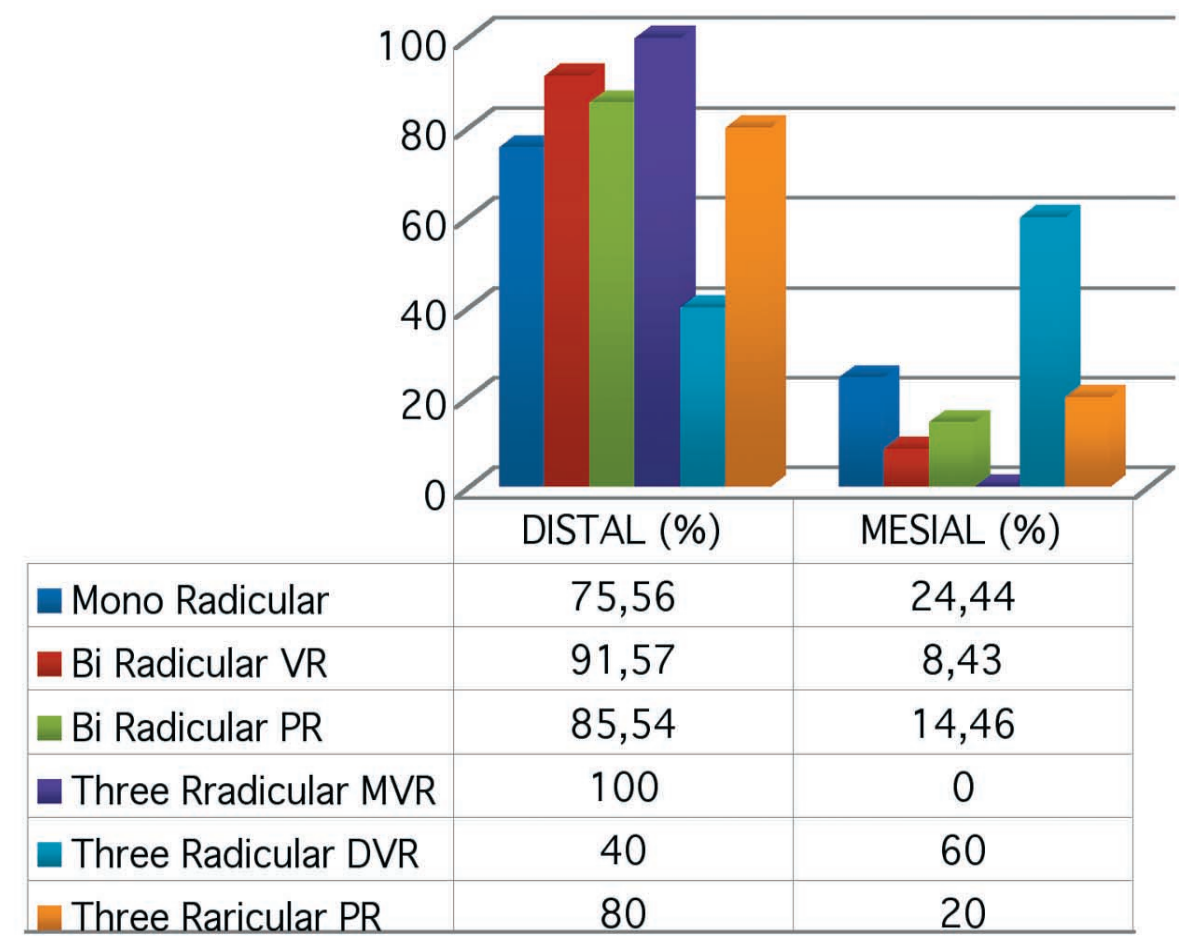

Fig. 1. Percentage of the radicular inclination to distal or mesial. VR - vestibular root; $\mathrm{PR}$ - palatine root; MVR - mesiovestibular root; DVR - distovestibular root. 
Table I. Average of the radicular length (millimeters)

\begin{tabular}{lc}
\hline Root Type & Radicular Lenght \\
\hline Mono radicular & 14.39 \\
& VR -13.43 \\
Bi radicular & PR -13.09 \\
& MVR -11.25 \\
Three radicular & DVR -10.56 \\
& PR -11.91 \\
\hline
\end{tabular}

VR - vestibular root; PR - palatine root; MVR - mesiovestibular root; DVR - distovestibular root.

To obtain the radicular inclination percentage, we examined the roots with naked eye, observing the inclination (whether it was to the mesial or distal).

In the mono radiculars, the radicular inclination to distal was $75.56 \%$. In the bi radiculars the radicular inclination to distal occurred in $91.57 \%$ of the vestibular roots and in $85.54 \%$ of the palatine roots. In the three radiculars, in $100 \%$ of the cases, the mesiodistal root is turned to distal; the palatine root was found turned to distal in $80 \%$ of the cases and at $60 \%$ of the cases the distovestibular root was turned to mesial (Fig. I).

Regarding the furcation location it could be observed that in the bi radiculars it is located, in $56.63 \%$, of the cases, at the apical third and in $43.37 \%$ of the cases at the middle third. At the three radiculars, in $100 \%$ of the cases it is located at the middle third.

\section{DISCUSSION}

In our study we could notice that the radicular morphology in the upper first premolars is variable and can be presented as mono, bi or three radicular.

We agree with Visser (1948), Walker (1987), and Pécora et al. (1991) when they affirm that most of the upper first premolars have only one root. This statement, however, is not shared by other authors seeing that Hess (1925), Müeller (1933), Bourdelle et al., Sicher \&Tandler, Pucci \& Reig (1944), Diamond (1952), Alves (1962), Wheeler (1974) Brand \& Isselhard (1977), Picosse, Vertucci \& Gegauff (1979), Della-Serra \& Ferreira, Deus (1986), Figún \& Garino, Silva \& Pécora, Chaparro et al. (1999), Madeira e Woelfel \& Scheid affirm that the majority of teeth are bi radiculars and that the three radicular are rarely found.

We also agree with Della-Serra \& Ferreira, Figún \& Garino, Silva \& Pécora, Woelfel \& Scheid and Madeira when they claim that, in most of the teeth, the inclination of both roots (vestibular and palatine) of the bi radiculars is to distal. To Sicher \& Tandler, both the bi radicular and mono radicular roots are inclined to distal. This statement meets the results obtained in our study.

Diamond, Brand \& Isselhard, Della-Serra \& Ferreira, Figún \& Garino, Silva \& Pécora, Woelfel \& Scheid and Madeira claim that in bi radicular teeth the palatine root is shorter than the vestibular root, this results were similar to the ones found in our study.

Silva \& Pécora claim that in the three radicular, the palatine root is higher in relation to the vestibular ones. In our study, although we found a reduced number of three radicular teeth, the same result was noticed. These authors have also claimed that the location of the furcation in the three radiculars occurs from the apical third to the half of the root, what it attested by Woelfel (1990). In our material, concerning the three radicular group, in $100 \%$ of the cases the furcation is in the middle third.

Marseillier (1937) found an average of radicular length of $14.5 \mathrm{~mm}$ in the mono radiculars, this value was very similar to the one we found, that was of $14.39 \mathrm{~mm}$. However, other authors who have also studied the middle radicular length in mono radiculars teeth, found very different values when compared to ours. Woelfel \& Scheid claim that the middle radicular length in the mono radiculars is of $13.4 \mathrm{~mm}$. Broomell \& Fischelis (1910), found an average radicular length of $12.0 \mathrm{~mm}$. Sauvez et al. (1914) found an average of $12.5 \mathrm{~mm}$. Diamond found the average of $12.19 \mathrm{~mm}$. Sicher \& Tandler and Figún \& Garino found an average of $13.0 \mathrm{~mm}$.

In our study we could conclude that: 1 - the upper first premolars mono radiculars presented an average radicular length higher than the bi radiculars and these ones, higher than the three radiculars; 2 - the upper first premolars bi radiculars presented an average radicular length higher for the vestibular root in relation to the palatine root, both roots presents higher inclination percentage for the distal. The furcation can be located in the middle third as well as in the apical third; 3 - the upper first premolars three radiculars present an average radicular length higher for the palatine root in relation to the vestibular roots. The radicular inclination is variable, and the distovestibular root presents higher inclination percentage for the mesial while the other roots for the distal. The furcation is located, in all the cases, at the middle third. 
ALVES, N. Estudios morfométrico y morfológico de las raíces dentales de primeros premolares superiores. Int. J. Odontostomat., 4(2):111-115, 2010.

RESUMEN: El conocimiento de la anatomía dental, principalmente la porción radicular, es de gran importancia para algunas especialidades, como la endodoncia y periodoncia. El objetivo de este estudio fue analizar la morfometría radicular de los primeros premolares superiores, el control de la longitud media de las raíces, y también, sus inclinaciones y la ubicación del área de furca en bi y tri-radiculares. En este estudio se utilizaron 659 primeros premolares superiores humanos pertenecientes al Departamento de Morfología de la Facultad de Odontología de Araraquara, UNESP, Brasil. Los dientes fueron previamente seleccionados, de modo que sólo los que tienen raíces perfectas fueron utilizados. Los dientes se dividieron en tres grupos: mono radiculares, bi radiculares y tri radiculares. Después de haber sido separado, algunas medidas específicas con un caliper digital, Brown \& Sharp se realizaron en cada grupo. En nuestro estudio podemos concluir que: 1 -Los primeros premolares superiores mono radiculares presentan una longitud radicular promedio más alto que los bi radiculares y estos, por sobre los tri radiculares, 2 - los primeros premolares superiores bi radiculares presentaron una longitud radicular promedio más alto para la raíz vestibular en relación a la raíz palatina, además las raíces presentan un mayor porcentaje de inclinación hacia distal. La bifurcación puede ser localizada en el tercio medio, así como en el tercio apical, 3 - los primeros premolares superiores tri radiculares presentan una longitud radicular promedio más alta en la raíz palatina en relación con las raíces vestibulares. La inclinación radicular es variable, y la raíz distovestibular presenta mayor porcentaje de inclinación mesial, mientras que las demás raíces hacia distal. La trifurcación se encuentra, en todos los casos, en el tercio medio.

PALABRAS CLAVE: primer premolar superior, morfometría, raíz dental.

\section{REFERENCES}

Alves, E. Anatomia Odontológica. 1ª Edição. Rio de Janeiro, Atheneu S.A., 1962.

Black, G. V. Descriptive anatomy of the Human Teeth. $4^{a}$ Edição. Philadelphia, The S. S. White Dental Manufac. Co., 1897.

Bourdelle, E.; Bennejeant, C. H. \& Wicart, A. Anatomie et Physiologie Bucco-Dentaire. Anatomie Dentaire Comparée. 4. ${ }^{a}$ edição. Paris, J. B. Baillière et Fils, 1937.

Brand, R. W. \& Isselhard, D. E. Anatomy of orofacial structures. Saint Louis, The C. V. Mosby Company, 1977.

Broomell, I. N. \& Fischelis, F. Anatomy and histology of the mouth and teeth. 3 . $^{\text {a }}$ edição. Philadelphia, P. Blakiston's Son \& Co., 1910.

Chaparro, A. J.; Segura, J. J.; Guerrero, E.; JiménezRubio, A.; Murillo, C. \& Feito, J. J. Number of roots and canals in maxillary first premolars: study of an Andalusian population. Endod. Dent. Traumatol., 2:65-7, 1999.

Deus, Q. D. Endodontia. 4. ${ }^{\text {a }}$ edição. Rio de Janeiro, Mdsi, 1986.
Della-Serra, O. \& Ferreira, F. V. Anatomia Dental. 3. ${ }^{a}$ edição. São Paulo, Artes Médicas, 1981.

Diamond, M. Dental anatomy: including anatomy of the head and neck. 3. ${ }^{a}$ edição. New York, Macmillan, 1952.

Figún, M. E. \& Garino, R. R. Anatomia Odontológica funcional e aplicada. 2. ${ }^{\text {a }}$ edição. São Paulo, Panamericana, 1989.

Fischer, G. Ueber die feinere Anatomie des Wurzelkanale menschlicher Zähne. Deutsche Monatschr. F, Zahnheilkunde, 1907.

Hess, W. The anatomy of the root-canals of the teeth of the permanent dentition. New York, W. W. Co., 1925.

Madeira, M. C. Anatomia do dente. 2. ${ }^{a}$ edição. São Paulo, Sarvier, 2000.

Marseillier, E. Les Dents Humaines. Paris, Gauthier Villars, 1937.

Müeller, A. H. Anatomy of the root canals of the incisors, cuspids and bicuspids of the permanent teeth. $J$. Am. Dent. Assoc., 20(8):1361-86, 1933. 
Mühlreiter, E. Anatomie des menschlichen gebisses. 3. ${ }^{a}$ ed. Leipzig, Arthur Felix, 1870.

Pécora, J. D.; Saquy, P. C.; Sousa Neto, M. D. \& Woelfel, J. B. Root form and canal anatomy of maxillary first premolars. Braz. Dent. J., 2(2):8794, 1991.

Picosse, M. Anatomia dentária. 3. ${ }^{a}$ edição. São Paulo, Sarvier, 1979.

Pucci, F. M. \& Reig, R. Conductos Radiculares: anatomia, patologia y terapia. Montevideo, Casa A. Barreiro y Ramos, 1944.

Sauvez, E.; Wicart, A. \& Lemerle, G. Anatomie et Physiologie de la Bouche et des Dents. In Manuel du Chirurgien-Dentiste. 3. ${ }^{a}$ edição. Paris, J. B. Baillière et Fils, 1914.

Schwartz, J. R. Practical Dental Anatomy and Tooth Carving. New York, Dental Items of Interest Publish. Co., 1935.

Sicher, H. \& Tandler, J. Anatomia para Dentistas. 2. ${ }^{a}$ edição. Barcelona, Labor, 1942.

Silva, R. G. \& Pécora, J. D. Anatomia dental: dentes permanentes. 1. ${ }^{a}$ edição. São Paulo, Santos, 1998.

Vertucci, F. J. \& Gegauff, A. Root canal morphology of maxillary first premolars. J. Am. Dent. Assoc., 99(2):194-8, 1979.

Visser, J. B. Beitrage zur kenntnis der menschlichen zahnwurzelformen. Zürich, Inaugural Dissertation, 1948.

Walker, R. T. Root form and canal anatomy of maxillary first premolars in a Southern Chinese population. Endod. Dent. Traumatol., 3:130-4, 1987.

Wheeler, R. C. Dental Anatomy, Physiology and Oclusion. 5. ${ }^{a}$ edição. Philadelphia, W. B. Saunders, 1974.

Woelfel, J. B. Dental anatomy: its relevance to dentistry. 4. ${ }^{a}$ edição. Philadelphia, Lea \& Febiger, 1990.

Woelfel, J. B. \& Scheid, R. C. Anatomia dental - sua relevância para a Odontologia. $5 .^{\mathrm{a}}$ edição. Rio de Janeiro, Guanabara Koogan, 2000.
Correspondence to:

Nilton Alves

Unidad de Anatomía Normal

Facultad de Ciencias de la Salud

Universidad de Talca

Avenida Lircay s/n

Talca - CHILE

Email: niltonnalves@yahoo.com.br

Received: 12-02-2010

Accepted: 21-04-2010 
